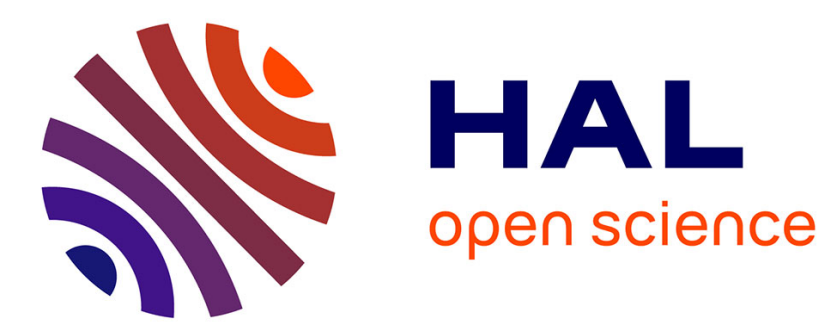

\title{
Economic freedom in Muslim countries: an explanation using the theory of institutional path dependency
}

François Facchini

\section{To cite this version:}

François Facchini. Economic freedom in Muslim countries: an explanation using the theory of institutional path dependency. European Journal of Law and Economics, 2013, 36 (1), pp.139-167. 10.1007/s10657-011-9250-y . hal-00636998

\section{HAL Id: hal-00636998 https://hal.science/hal-00636998}

Submitted on 2 Nov 2011

HAL is a multi-disciplinary open access archive for the deposit and dissemination of scientific research documents, whether they are published or not. The documents may come from teaching and research institutions in France or abroad, or from public or private research centers.
L'archive ouverte pluridisciplinaire HAL, est destinée au dépôt et à la diffusion de documents scientifiques de niveau recherche, publiés ou non, émanant des établissements d'enseignement et de recherche français ou étrangers, des laboratoires publics ou privés. 


\title{
Economic freedom in Muslim countries: an explanation using the theory of institutional path dependency
}

\begin{abstract}
This article explains the level of economic freedom in Muslim countries through the theory of institutional path dependency. Islamic countries are generally not free and they have a poor record regarding property rights. To explain these realities we use the institutional history of Muslim countries. We define three steps: the Arab and Ottoman Empires when Islamic law was of great importance, European colonisation, and the contemporary era with its movement towards a revival of Islam. Islamic law is not liberal. This explains why, in general, Muslim countries are generally not free. Colonisation radically changed institutional life in the twentieth century. British colonisation proved to be better than did French or Soviet colonisation. This explains why the Persian Gulf countries are freer. The collapse of the Soviet model explains the speed of liberalisation in former socialist countries (such as Albania, Kyrgyz Republic, and Kazakhstan). Nevertheless, the twentieth century was not just the century of Westernisation. It was also the century of the revival of Islam. The article concludes that the history of the twentieth century does not explain the way in which Muslim countries are attracted by the ideal of the Muslim city. The revival of Islamic intellectual innovations and the evolution of Muslim opinion sustain this thesis. Therefore, there is a dependency on the past and on an imagined future. Islam acts, like yesterday, on the world of institutional possibilities.
\end{abstract}

Keywords Economic freedom, colonisation, imaginary, Islam, property rights JEL: KOO, N23.

\section{Introduction}

The objective of this article is to explain the relationship between Muslim countries and economic liberalism. Like all the econometric literature about economic freedom and GDP growth (European Journal Political Economy, 2003, Gwartney, Lawson and Holcombe, 1999, de Vanssay and Spindler, 1994, Spindler, 1991, Scully, 1988) that evaluates this relationship one can refer to the indexes of economic freedom proposed by American nonprofit organisations: Fraser or Heritage. In the 2009 report of the Index of Economic Freedom (www.heritage.org), we learn that North America and Europe enjoy far greater levels of economic freedom than do those who live in other regions of the world. On this indicator, Muslim countries are 'less free'. In addition, there are differences among Muslim countries: Oman, Qatar, Kuwait, Jordan, UAE, Malaysia, Saudi Arabia, Albania, Kyrgyz Republic, Turkey, and Kazakhstan are described as 'moderately free' and Bahrain is 'fairly free'. But what determines these divergent models of economic freedom between West and East and more generally among Muslim countries?

To answer at this question, we use the contribution of new institutional economics (NIE). NIE is a combination of theories from different traditions (Brousseau and Glachant, 2008). NIE focuses on the belief that humans develop to explain their environment and the institutions (political, economic, and social) that they create to shape that environment (North, 2005, p. 11). From this perspective, we connect the contributions of Austrian economics and North to explain institutional design and its change. The contribution of Austrian theory is to award a place to tacit knowledge acquired by the actors by abstract rules and transmitted throughout organic institutions. For this reason, capitalism by fiat, according to Pejovich (2008), would be doomed to failure because humans must have confidence in these institutions. They must believe that they are just; the feeling of injustice makes the graft of institutions of economic freedom inefficient. If the ruling elite anticipate this effect, they block reforms because they anticipate that they will fail. The people thereby do not share free market ethics, and the free market would not, under these conditions, have the effect it might in a more favourable ethical environment. The status quo is not only connected to political calculations of the elite of interest groups. It has also its origins in people's values. In these conditions, cultural change 
or indigenously introduced endogenous institutions (Boettke, Coyne and Leeson, 2008, p. 337 ) is a prerequisite to the implementation of institutions favourable to economic growth (respect of economic freedom). Therefore, the institutional design of each country is determined by its ethic path dependency.

The past connects with the present and future to create the path dependency (North, 1990, pp. 92-94, 2005, p. 2) of the institutional structure, i.e. "the combination of formal rules informal constraints, and their enforcement characteristics" (North, 2005, p. 6). Institutions are hard to change and they have tremendous effects on the possibilities for generating sustained economic growth (Pierson, 2000, p. 256). Then, the institution structure imposes severe constraints on the choice set of entrepreneurs when they seek to innovate or modify institutions (North, 2005, p. 2). The underdevelopment of the Muslim world can explain these path dependencies, which tend to lock in particular institutional arrangements. This article applies this model to explain the low level of economic freedom in the Muslim world and the differences among countries. In the long-term, this explains the limited convergence of economic performance across countries over time and the continued divergence in GDP per capita between West and East.

The empirical issue of the article is to apply this theory of institutional path dependency to explain the level of economic freedom in the Muslim world. As Sutcliffe (1975), Kuran (2004b, pp. 71-72), or Hillman (2007) explain, the Muslim world is poor and underdeveloped today as a result of certain Islamic institutions (Islamic egalitarian inheritance system, absence of the concepts of limited liability and Waqf), which have had the unintended effect of being obstacles to economic development. This article assesses the history of Islamic Law to explain why, on the one hand, the Muslim world is not free, and, on the other hand, economic freedom does not exist in Muslim culture. East and West, to simplify, have different institutional structures but the same path dependence. East and West have different ethic roads. When the West colonised the East and other Muslims countries (in Africa and Asia) it developed tensions between the informal constraints of Muslim countries and Western formal rules. The main origin of the informal constraints in Muslim countries is religion because the dominant organised belief structure (North, 1997, p. 5) is Islam. In this context, Islam imposes specifies norms and learning processes by which a particular belief structure evolves (North, 1997, p. 5). This learning process constrained and constrains the institutional choices of governments in the Muslim world.

The theoretical issue is the existence of two institutional path dependencies: dependency on the past and addiction to the future through the imagination of institutional possibilities. According to North (1990, pp. 92-94, 2005, p. 52), path dependence is a factor in the continuity of a (Muslim) society but it is not inertia. It constrains the choice set in the present, which is derived from the historical experiences of the past (North, 2005, p. 52).

Dependence on the past does not only affect the cost of institutional change. It also has an effect on the imagination, or the definition of institutional possibilities. The ideal of a Muslim city plays the same role as that of the ideal of classical liberalism. It inspired the Muslim right to enforce the institutions of capitalism. Muslims possess in their world institutional possibilities, the choice of Shari'a, the ideal of the Muslim city. They can imagine an Islamic future because they are converted to Islam. The institutional dependence path is dependent upon a world of possibilities. The past does not only determine the future, but also the imagined futures. Christian or secular countries do not integrate into their worlds the possible future choices of Shari'a. They do not attempt to evaluate its chances of success or its value 
for the national community. The rules of Muslim countries and more generally the political forces evaluate the opportunity of such an alternative to capitalism or socialism. All Muslim countries, despite their differences, share this imagery because it is determined by their conversion to Islam. They are all different countries; their geographies, their histories, their populations and their geopolitical situations distinguish them but they all adhere to the project of the ideal Muslim city. It is this ideal that the institutional path dependency theory describes.

This article explains the level of economic freedom in Muslim countries through the theory of institutional path dependence. The first section describes the property rights and economic freedom (Heritage foundation) in Muslim countries and explains why in general this area of civilisation is less free and why the ethic road of this area is not economic liberalism. The second section shows the consequences of European colonisation and political choice. These historical events explain the differences among Muslim countries. Colonisation radically changed institutional life in the twentieth century; however, British colonisation has proven to be better than has French or Soviet colonisation. This explains why the Persian Gulf countries are rather freer. Nevertheless, the twentieth century was not just the century of Westernisation. It was also the century of the revival of Islam. The third section discusses how the evolutions of economic freedom (1995-2007), the revival of Islamic intellectual innovations, and the evolution of Muslim opinion affected institutional evolution in the Muslim world. Islam acts, like yesterday, on the world of institutional possibilities.

\section{Why are Muslim countries less free?}

According to the Economic Freedom index, some Muslim countries are less free (Table 1).

Table 1

Economic Freedom by Region (2009)

\begin{tabular}{|c|c|c|c|c|c|c|}
\hline $\begin{array}{c}\text { North } \\
\text { America }\end{array}$ & Europe & $\begin{array}{c}\text { South and Central } \\
\text { America/Caribbean }\end{array}$ & $\begin{array}{c}\text { Middle } \\
\text { East/North } \\
\text { Africa }^{1}\end{array}$ & $\begin{array}{c}\text { World } \\
\text { Average }\end{array}$ & $\begin{array}{c}\text { Asia } \\
\text { Pacific }\end{array}$ & $\begin{array}{c}\text { Sub-Saharan } \\
\text { Africa }^{2}\end{array}$ \\
\hline 75.7 & 66.3 & 60.1 & 60.0 & $\mathbf{5 9 . 5}$ & 57.6 & 53.1 \\
\hline
\end{tabular}

Source: Heritage foundation report 2009 (Chapter 5).

The Heritage Foundation index is a simple average of ten indicators of individual freedom (Beach and Kane, 2008, p. 39). Each indicator measures a type of freedom such as business freedom, free trade, fiscal freedom, size of State, monetary freedom (stability and price control), freedom to invest, financial freedom, property law (security) level of corruption, and freedom of contracts in matters of work. Business freedom is the capacity to create, manage, and close a company rapidly and easily. Free trade measures the absence of tariff and nontariff barriers, which affects imports and exports. Fiscal freedom measures the charges the government applies to citizens' incomes. The size of government measures the freedom to choose the types of goods and services consumed. Monetary freedom measures price stability (inflation tax) and the freedom to fix prices. Freedom of investment is the facility of access

\footnotetext{
${ }^{1}$ Middle East/North African Countries: Bahrain, Israel, (score 67.6) Oman, Qatar, Kuwait, Jordan, United Arab Emirates, Saudi Arabia, Lebanon, Egypt, Tunisia, Morocco, Yemen, Algeria, Syria, Iran, Libya, Iraq.

${ }^{2}$ Sub-Saharan African countries: Mauritius, Botswana, South Africa, Uganda, Namibia, Madagascar, Cape Verde, Burkina Faso, Swaziland, Kenya, Tanzania, Ghana, Zambia, Senegal, Gambia, Mozambique, Mali, Benin, Nigeria, Gabon, Ivory Coast, Rwanda, Mauritania, Niger, Malawi, Ethiopia, Cameroon, Djibouti, Equatorial Guinea, Guinea, Lesotho, Burundi, Togo, Central African Republic, Liberia, Sierra Leone, Seychelles, Chad, Angola, Guinea-Bissau, Rep. Of Congo, Sâo Tomé and Principe, Comoros, Dem Rep of Congo, Eritrea, Zimbabwe, Sudan.
} 
capital, more particularly foreign capital. Financial freedom measures banking security and independence in relation to government. Public ownership of banks and financial institutions is contrary to financial freedom. Ownership rights measure individual capacity to accumulate property rights without it being threatened by the state (Table 2). Furthermore, the level of corruption measures the equality of individuals before the law. Freedom on the employment market evaluates contractual freedom. Each of these indicators has an equal weight. This list moderates the pertinence of global indicators when evaluating the effect of economic freedom on economic growth.

Table 2

Property Freedom (average) and Religion (2009)

\begin{tabular}{|c|c|c|c|c|c|c|c|c|c|}
\hline Protestant & $\begin{array}{c}\text { Catholic } \\
\text { Western } \\
\text { Europe }\end{array}$ & $\begin{array}{c}\text { Catholic } \\
\text { Eastern } \\
\text { and } \\
\text { Central } \\
\text { Europe }\end{array}$ & $\begin{array}{c}\text { No } \\
\text { majority }\end{array}$ & Orthodox & Buddhist & $\begin{array}{c}\text { Islam } \\
\text { Arab }\end{array}$ & $\begin{array}{c}\text { Ex } \\
\text { USSR }\end{array}$ & $\begin{array}{c}\text { Black } \\
\text { African } \\
\text { Catholic }\end{array}$ & $\begin{array}{c}\text { Black } \\
\text { African } \\
\text { Muslim }\end{array}$ \\
\hline 84.5 & 76.3 & 59.5 & 44.4 & 39.1 & 38.5 & 38.1 & 23.3 & 37.27 & 26.7 \\
\hline
\end{tabular}

Sources: Heritage foundation report, author's calculation of averages. Property Freedom.

If we follow the perspective opened by the theory of institutional path dependencies, one can find the explanation for low average indicators of economic freedom in the Muslim world and its diversity across countries by studying the institutional trajectory of each country (Table 4). History, from this perspective, is important because the sequence of events determines current values (Liebowitz and Margolis, 1995, p. 223). The sequence is pre-Islamic, Islamic, Ottoman, colonisation, and independence. The formal institutions of these countries are different from other countries because, on the one hand, the sequence was different, and, on the other hand, Muslims possess in their world of institutional possibilities the choice of Shari'a. Christian or secular countries do not integrate into their worlds the possible future choices of Shari'a.

Islamic law differs in many aspects to the ideal of liberal order. It justifies an economic model of rent. This does not mean that Islamic law is the only legal tradition that is unfavourable to economic liberalism. Cultural factors, with political will, interest group action, and political decisions, explain why Muslim countries are generally less free. This creates an ethical context that is unfavourable to liberalisation. This first section of this chapter defines briefly the history of Islamic law (2.1), explains why its ideal is not liberal from a modern viewpoint (2.2), and describes how this ideal justified the rent models of Arab and Ottoman empires (2.3).

\subsection{Islamic Law}

If we follow the theory of institutional path dependency, Islamic law explains a part of institutional reality today. Islamic law is derived from an interpretation of sacred texts revealed to the Prophet by God (Coulson, 1995, Montgomery Watt, 1968, Schacht, 1964, Aldeeb Abu-Sahlieh, 2006). It commenced around AD 609-632 in the Arabian Peninsula with the Prophet's revelations. The four main sources of Muslim law are the Koran, the Sunnah, the Idjma and the Kiyas or Akl (Scully, 1987, Sait and Lim, 2006, Aldeeb AbuSahlieh, 2006). The Koran is the first source of Muslim law. It is the sacred book of Muslims. This text is the word of God revealed to the Prophet. The Prophet is he who reveals information that originates from a beneficial (Allah) or evil (the devil) source (Aldeeb AbuSahlieh, 2006, p. 60). The Sunnah is the tradition or the precedents of Islam. It is transmitted 
from generation to generation by Muslims among themselves. The Shiites reject the Sunnah companions of the Prophet but accept the Sunnah people of the house of the Prophet as a source of law (Aldeeb Abu-Sahlieh, 2006, pp. 123-128). The Idjma is a body of doctrine or practices universally accepted by Muslims. The Kiyas is the result of jurists' logical analogue reduction on the origin of the law for Sunnites (not for Shiites).

The role of Islamic law in Muslim societies is the subject of contentious debate among Muslims (Brown, 1997, p. 359). There are two positions. For the first, Islamic Law is a right without practice (Brunschvig, 1976, p. 119, Denoix, 1996, p. 11). The nature of Islamic law is largely determined by its history and this history is dominated by the contrast between theory and practice (Schacht, 1964, p. 165). For the second, Islamic Law dominates the practice and unifies the Muslim world around the same system of rule. The laws and customs of the conquered countries were gradually integrated into Islamic law, over the years, through the practice of fiqh. The figh is Islamic jurisprudence. It is an expansion of Islamic Law and gives the impression of juridical unity in the Muslim world (Denoix, 1996, Tyan, 1977). The Muslim world shares this juridical practice, this same reference of Islamic law, as well as an ideal of society. This ideal and this practice have influenced the world of the institutional possibilities of the people of these countries and helps explain why Muslim countries are less free.

\subsection{Islamic Law and Free Market Ideal}

One characteristic of Islamic law that differs from the capitalist ideal is that it considers sacred a certain number of inequalities (Section 2.2.1), restricts the freedom of ownership on moral principles (Section 2.2.2), and promotes the collective ownership of natural resources (Section 2.2.3) and ruling over spoils (Section 2.2.4). Islamic law founds and justifies formal institutions that contrast with free market institutions, which legitimise a culture of rent (2.2.5) (Al Jabri, 2007, Hillman and Ursprung, 2000).

\subsubsection{Unequal property}

The protection of property is pronounced in Islamic law (Schacht 1964, p. 118), but it does not guarantee the formal equality of citizens before the law. From a general point of view, Islamic law recognises human, public, and private rights (Khadduri, 1946, pp. 77-78, Habachy, 1962). The first difference between the West and East concerns the basis of ownership. The West bases ownership on a secular basis, while the East uses religious bases (Habachy, 1962, p. 453). All human rights are God's privilege, as all authority comes from God. God is, according to this theory, indirectly at the head of the Islamic state (Khadduri, 1946, p. 79). God dictates the law through the words of the Prophet. Human rights are the privilege of those who have full legal capacity. A man has full legal capacity if he is an adult, free, and of Muslim faith. It follows from this principle that non-Muslims and slaves who live in an Islamic state have rights that are only partly protected (Khadduri, 1946, p. 79). It is the case in the most societies. "Human persons are seen as being able to be holders of property relationship. But usually such capacity is constructed with the help of qualifiers. On the basis of criteria of gender, age, mental state, or social status, certain persons may be deemed to be incapable of holding property of their own" (Von Benda-Beckmann, 1995, p. 313). Islamic law sanctifies three formal inequalities (Voigt, 2005, p. 65): master-slave relationships, which define the concept of freedom in Muslim society (Montgomery-Watt, 1968, p. 113, Lewis, 2005, pp. 919-933), male-female relationships, and relations between believers and nonbelievers. 


\subsubsection{Restricted ownership}

Islamic law, secondly, does not give the owner free use of his or her property. The owner is forced to accept moral rules that apply to everyone. He or she has obligations towards the community as this is God's precept, in exchange for which he or she can exercise rights of private use over these possessions (Gardet, 1930, p. 112). Ownership does not come first. It depends upon superior moral principles, which include the submission of man to God and His principles. These principles restrain ownership rights in several ways. Individual freedom, otherwise stated as the use of one's property, is limited by the prohibition of use, obligation to pay tax for the poor (Zakat), succession rights, the absence of a legal entity, collective lands, the higher right of the state to the land, and the prohibition to appropriate water and grass for oneself. All these restrictions are the origins of institutions, which are distinct from free market institutions.

(1) In ancient times, loans with interest, financial trading, and the rental of capital were formally condemned by Islamic law. However, Muslim jurists quickly found solutions to get around the law and resort to credit. Rather than lend money to buy a house, the bank bought the house and rented it. The result of this prohibition harmed the development of a capitalist banking and financial system in the East.

(2) Zakat (Sura 21, v. 73) justifies redistribution.

(3) Succession rules in favour of the non-division of Muslim land, namely judicial situations where at least two persons have common title to the same nature exercised on the same property or set of properties without there being material division of their shares. This also covers insecurity for non-Muslim lands. Non-division limits the concentration of wealth. More generally, it threatens the succession of companies and all capital of one generation to another (Kuran, 2004a). This has the effect of applying the civil code to land division in France. Muslim succession rights fragmented fortunes and had the unintentional effect of limiting innovation (Kuran, 2003, 2004b, p. 75). This reinforced the effect of the absence of legal entity on the dynamics of land accumulation in Muslim lands.

(4) The absence of legal entity prevented the emergence of collective enterprises that had legal rights distinct from those of individuals who finance them (corporations). Kuran (1995) thereby explains why the finances of the Middle East before AD 1000 were made without banks and without a credit market in the modern sense of the term. The incertitude about the legitimacy of interest and the lack of corporate law led to contracts where borrowers and lenders were individuals (Kuran, 1995, 2004b, p. 73). This also had the effect of limiting investment, innovation, and growth. The rigidity of Muslim law prevented the countries submitted to it from developing large-scale enterprises capable of exploiting scale economies and developing new technology.

\subsubsection{Collective ownership of natural resources}

Islamic law legitimises, thirdly, the public and common ownership of land ${ }^{3}$, which were the most common forms of ownership in Arab and Ottoman Empires. It prevents the privatisation and realisation of liberal order where individual rights are exclusive and transferable. The basic rules were the nationalisation and inalienability of land. It is Omar and not the Prophet that is behind this system. Omar resumed by this practice the old principles of collective tribal ownership. There is, on this topic, a continuum between pre-Islamic traditions and Islam (de Planhol, 1968, p. 54). In Islamic law, there are several types of land ownership: state property,

\footnotetext{
${ }^{3}$ See Sylvie Denoix, special number of Revue des mondes musulmans et de la Méditerranée, Année 1996, volume 79, $\mathrm{Nr} 1$, dedicated to "Biens Communs, patrimoines collectifs et gestion communautaire dans les sociétés Musulmanes".
} 
the ownership of conquering Arabs and non-Arabs, the ownership of non-Muslims, the ownership of religious institutions (Waqf), and collective property (Linant de Bellefonds, 1959, p. 121, Denoix, 1996). We can distinguish, also, private appropriation (milk), collective appropriation (gamâe), the commons, and public property. We find these forms of ownership in the Ottoman Empire (Bozarslan, 1988). The Ottoman Empire also possessed a mosaic of property ownership: Miri, Jiftlik, Mahlul, Matruka, Mawat, Waqf Mulk, and Musha. They were private or public (Miri, Jiftlik). Only Mulk was similar to Western ownership, which was private property owned in complete freehold. The land could be transferred to others without state interference, and owners could mortgage it or bequeath it. Such ownership was rare in many countries.

Miri and Jiftlik, on the contrary, were perhaps the most common form of land ownership. Individuals could purchase a deed to cultivate this land and play a tithe to the government plus an additional tax. Jiftlik was land that had been bequeathed to the Sultan by its owners. It could be rented out directly to tenants. These State properties were built during the first caliphate of land possessed by the warriors who fought Islam. The Caliph had the right to appropriate one fifth of the spoils after a conquest, the occupied land.

Matruka was, also, public ownership. It was land set aside for public use such as highways. Mawat was land that was declared unsuitable for any purpose, generally desert or swamp. The existence of a collective or common property, the extent of which was difficult to determine in remote times and sometimes even today, is explained by two main hadiths ${ }^{4}$, the third being of lesser magnitude (Linant de Bellefonds 1959, p. 121). The non-appropriable nature of land results not from its own nature (as there exist private pastures and appropriated forests) but from the principle consecrated by the Sunna that some things are a gift from God to which consequently everyone has an equal right (Linant de Bellefonds, 1959, p. 123). These lands permanently became common res. They can no longer be anyone's property. Inevitably, the common res represent a risk to the of destruction of natural pastures or forest patrimony (Linant de Bellefonds, 1959, p. 114). This tragedy of common pasture exists for all natural resources: common land, water, grass, and fire, as well as deposits of asphalt or salt.

To conclude Waqf was the lands given to religious and charitable institutions. In precommercial society, Waqf would ordinarily be arable land, farms, or oases. Waqf is a religious endowment or the public body that manages the endowment in some cases. It may be a land or trust investment or any other kind of property. The basic regulations governing Waqf trusts are laid down in Shari'a. These lands were exonerated partially or totally from taxation. Their incomes may finance mosques, religious institutions, or charities. Waqf with Miri was one of the legal modes of land ownership prevalent in the Ottoman Empire. For some observers, Waqf was at the origin of behaviour that was unfavourable to the economic development of countries in the Muslim area (Shatzmiller, 2001, Cahen, 1961, Kuran, 2004b, pp. 71-72). Economists rapidly condemned immobilisation for the perpetuity of vast expanses of land, which excluded them from the market and represented mortmain property (Coulson, 1995, p. 190).

\subsubsection{Acquiring property with spoils}

Contrary to liberal traditions, a man can acquire property by conquest and spoils. "That which God gives to his messenger as spoils collected at the cost of the inhabitants of the cities belongs to God and his messenger, to those close to him, to orphans, to the poor, the traveller so that the remains are not shared only among the rich among you" (Sura 8 Koran). These spoils do not essentially concern personal effects. It also allows the appropriation of property

\footnotetext{
${ }^{4}$ The hadiths are texts that retrace the words or acts of Mohammed and are generally referred to as the Sunna ("tradition").
} 
such as land (Linant de Bellefonds, 1959, p. 121, Denoix, 1996, Facchini, 2010). Muslim law produced a doctrinal link between spoils and war, which is generally associated with the concept of Jihad. The word Jihad means "effort to achieve an objective" and this objective is to assure God's reign. Jihad is both an internal combat for each Muslim to attain holiness and a combat against the enemies of Islam. Combating enemies of Islam justifies the spoils; it is the reward for conversion work that enables the conquest and the submission of non-believers to Muslim authority. Conquest and spoils are not sought for themselves but to convert the people and found a new state, legitimised by a new religion (Islam) (Al Jabri, 2007, p. 89). During this Meccan period, the success of Islam can be explained both by meeting the interest of urban dwellers and Bedouins (de Planhol, 1967) and the place to which the new religion gave the spoils and conquest (Al Jabri, 2007). On the death of the Prophet, Abu Bakr and Omar had probably used this spirit of conquest to maintain the unity between Bedouins and urban people (Montgomery Watt, 1956, de Planhol, 1968, pp. 28-29). Spoil is the emblem of this economy based on the raids and an unequal distribution of wealth. Islam legitimises conquests and founds the economic model of the predation of Arab and Turk models. The result is that "in Islamic societies, wealth and power have historically been concentrated in the hands of an absolute ruler and associated elites" (Hillman, 2007, p. 271). The proof is that since the rise of Islam in the seventh century, various dynasties have come to power including the Umayyads, Abbasids, Mamluks, Safavids, and the Ottomans. The Arab and Ottoman Empires never operated based on liberal capitalism. Muslim rights legitimise a rentseeking model.

\subsection{Islamic Law and the Rent-seeking Model}

Many works have described this rent-seeking model (Cheddadi, 1980, Chapra, 2007, Bozarslan, 1988, Carré, 1983, 1986, Al Jabri, 2007, Hillman, 2007). Like Russia (Hedlund, 2005) Islamic Law creating a virtual past. It provided the rulers with a religious myth that justified their claim for absolute control over all aspects of social life. The prosperity of the Arab and Ottoman Empires was based on military expansion and a religious state. Wars had two objectives: to expand the territory and to pillage it. War was in fact a war of colonisation. The central power was imposed on the Turks in order to implant themselves in new colonies to create unity.

Ibn Khaldûn's description of power in Islam shows clearly that the Empire's economic model is mercantile where wealth and law are associated with holding power (Cheddadi, 1980, p. 535). He who holds the power distributes the spoils. Khaldûn considers Islamic power based on the notion of Jah. Jah is the capacity of men to exercise their will over those who are their subjects. It is a social condition of exercising constraint that is considered necessary for life in society (Cheddadi, 1980, p. 536). Jah has two functions. Social well-being is a necessary function, whereas exploiting the work of others is an accidental function. Jah is thereby presented as a concept that competes with the concept of authority as a purely arbitrary function between men and the application of divine law; a concept defended by theologians and very present in the minds of Muslims. Jah is meant to be a positive description of the economic and social reality of power in Islam. However, economists show that one of the main sources of wealth, aside from hunting, breeding, agriculture, arts, and commerce, is the exercise of authority (Cheddadi, 1980, p. 544). Jah is a source of wealth because it provides the means to exploit the work of others. Passing from a tribal power to a central power in the Magreb, and before that in Makrech, under these conditions, it aims at the seizure of surplus by a small minority. This minority draws taxes, exploits the work of others, and usurps property (Cheddadi, 1980, pp. 544-546). Jah describes a predation model. 
Similarly, Weber upholds that if Muslim civilisation did not discover capitalism it is because Islam transformed its original ascetic extra-social monotheism into the military ethic. It is this warrior ethic - and the patrimonial structures and prebend determined by it - that hindered the rise of the state's spirit of capitalism (Carré, 1986, p. 141). Turner (1974) developed this thesis by explaining the way in which Medina society was structured with warriors and mystics. Such a world leaves little room for production as man either prays to God or makes war in God's name. War also allowed the raising of taxes.

The spending of taxes was the origin of the merchants' wealth in towns. The powerful (Arabs and then Turks) administered the Empire and took the dividends. Muslim Arabs occupied territories by placing garrisons in the cities and differentiated between Muslim and nonMuslim taxation. They established separate camps, living off the fruits of their conquests and the taxes paid by non-Muslims in exchange for their freedom and protection. They thus organised life for believers and non-believers. The Muslim presence became synonymous with the opportunity for exchange and led artists and merchants (Jews and Christians mainly) to offer their services. They incited some to convert in order to benefit from the same fiscal advantages as the believers did and others to remain Christian or Jewish in order to benefit from the possibility of offering services that the other beliefs could not propose (Bella, 2004) in the garrison cities where the Arab aristocracy resided. In this context, it was in the interest of Muslims to protect Christians and Jews. They paid taxes and participated actively in the prosperity of the Turkish and Arab Empire in the Orient (Bella, 2004). The triumph of commerce and the wealth of merchants was based on spending spoils acquired by the nobility or the occupying force. This Muslim aristocracy disengaged revenues from the fiscal system of the land. It incarnated the power of landowners (Benabdelali, 1999, p. 183 and p. 275) who lived off their land revenues and imposed the values of generosity and donation, which predominated in society and were contrary to the diffusion of the capitalist values of frugality and efficiency (Benabdelali, 1999). By socially dominating the merchants, the aristocrats maintained a donation economy that recycled agricultural surplus and created a blooming urban production sector (Benabdelali, 1999, p. 307). Schematically we could say that Muslim law incited the Arabs to become warriors or mystics and non-believers to do business. Thus, the law organised these roles.

The history of the rise of Islam as a civilisation illustrates the observation that the descendants of societies that were the first to have centralised government and organised religion ended up dominating the modern world. The union of government operated with its resulting fruits, writing and technology, as one of the four main sets of immediate elements that gave history its general configuration (Diamond, 1997, 2000, p. 272). The difficulty for these centralised regimes with a theocratic ideal based on predation revenue was to find the correct level of predation ${ }^{6}$. We then find ourselves in the configuration described by Baumol (1990) for the Chinese and Roman Empires. The Empires of India, China, or Germany in the Middle Ages, he states, collapsed because they asked too much from the producing people. This explains the decline and their political helplessness. For without a solid economic base, political authorities cannot finance armies or administrations; its military power is reduced and corruption within the administration results. It is because a society progressively values predation more than production that it declines in relation to societies that invent a better

\footnotetext{
${ }^{5}$ Bella (2004) explains the ambiguous relationship between Christians, Jews, and Muslims by the consequences on public finance from conversion to Islam. She upholds that the Ottoman Empire was a state respectful of free trade and the religions of the book because non-Muslims were the financial cornerstone of the warrior empire.

${ }^{6}$ The system of fiscal farms of the Ottoman Empire had the same effect. These fiscal farms (Iltizam), held for a short period, incited the owners to overexploit the peasants and ruin local agriculture.
} 
institutional system for production. The economic superiority of one civilisation over another is relative. By inventing capitalism, Europe discovered a more efficient means of controlling predators and gave itself the means to finance a powerful army that can itself engage in the resulting spoils. The logic of Arab Muslim believers versus non-believers is the story of a government model that suffocates entrepreneurial initiative, flatters predators' egos, and exhausts itself in military expansion, thereby limiting its survival conditions once another area discovers a more efficient institutional system, or succeeds better than do others at fighting parasitism and inciting cooperation (Zywicki, 2000, p. 87).

Islamic law derives its interpretation from the sacred texts of Islam, which do not predispose Muslim civilisation to discover (Facchini, 2010) or adopt free market institutions (Section 2). This created a culture unfavourable to economic freedom, which explains why in general the Muslim world is less free. The failures of liberalisation in Iraq and Saudi Arabia in the 1980s can also be explained by the characteristics of the cultural prerequisites. The experiences of these two countries demonstrate how difficult it is to create and sustain functioning market economies after long periods of étatisme (Chaudhry, 1994, p. 2).

\section{Why are some Muslim Countries Fairly Free?}

Nevertheless, some countries in the Muslim world are fairly free (Table 3, column 1) based on the level of economic freedom, which depends on the size of the state and amount of tax. When there is a 'rentier state' the size of the state and amount of tax are low and thereby the level of economic freedom is artificially high (3.1). Contemporary history may also explain these evolutions. The institutional design in Muslim countries is the result of colonial heritages (3.2) and political conflicts (3.3) (Shirley, 2004, pp. 616-629).

\section{1 "Rentier State" and Economic Freedom}

Many states in Muslim countries are rentier states in that they receive substantial rents from foreign individuals, concerns, or governments (Ross, 2001, p. 329). Countries that export oil, minerals, and/or workers are described as rentier states. Their public finances are sustainable without tax. Countries in the Persian Gulf have no fiscal system and their state sizes are small (Table 3). They are not free in terms of investment freedom, financial freedom, and ownership (Table 3, columns 1-5 and 10) and corruption is widespread. Many states with great mineral wealth and oil also have a large Muslim population in the Middle East, in parts of Asia (Indonesia, Malaysia, Brunei) and in Africa (Nigeria). This list of oil-producing countries also includes Libya and Algeria in North Africa, Indonesia, Malaysia, and Brunei in South Asia, Nigeria in Africa, and four republics of the former Soviet Union: Turkmenistan, Azerbaijan, Uzbekistan, and Kyrgyzstan. The economy of Tajikistan strongly depends on the production of aluminium and cotton. The economy of Turkmenistan is based on the export of natural gas. The main wealth of Azerbaijan is oil. Uzbekistan has significant potential in the fields of oil, gas, and gold and is the world's largest producer of cotton. Many states in the Muslim world also have a high level of immigration and remittances. Workers' remittances have also been an important source of foreign exchange in Egypt, Yemen, Syria, Lebanon, Tunisia, Algeria, and Morocco (Ross, 2001, p. 329) as well as in Mali and Senegal. Djibouti is a rentier state without oil. Its main source is income transfers from France and the USA for their military bases. The situation is similar in Egypt and Jordan, which are largely dependent on American aid. The US pays for military locations in these countries because of Israeli-Palestinian conflict. Somalia and Sudan are suffering from civil war, while the economy of Niger depends on uranium prices. Overall, Muslim countries are generally rentier states. 
Table 3 shows that the indicators of economic freedom in Muslim countries are much higher when governments do not raise taxes and have small-sized states. Gulf countries, in particular, display rent-seeking models (usually based around oil) (Al Jabri, 2007, Facchini, 2007). For these reasons, the level of economic freedom is not only the result of cultural prerequisites (religious factor) or political choices. It can also be explained by geographical determinants and the structure of economic sectors.

Table 3

Breakdown of Indicators of Economic Freedom for Muslim Countries by Region (2009)

\begin{tabular}{cccccccccccc}
\hline Countries & 2009 & 1 & 2 & 3 & 4 & 5 & 6 & 7 & 8 & 9 & 10 \\
Overall & 58.7 & 59.7 & 69.5 & 82.5 & 74.5 & 72.9 & 39.5 & 41.0 & 32.0 & 30.2 & 59.5 \\
Arabs & 58.7 & 63.4 & 69.8 & 86.3 & 70.1 & 73.4 & 43.9 & 45.0 & 38.1 & 36.6 & 60.3 \\
Arabian & $\mathbf{6 5 . 6}$ & $\mathbf{7 1 . 1}$ & $\mathbf{8 0 . 7}$ & $\mathbf{9 7 . 3}$ & $\mathbf{7 0 . 0}$ & $\mathbf{6 9 . 9}$ & $\mathbf{4 7 . 1}$ & $\mathbf{5 2 . 9}$ & $\mathbf{4 5 . 7}$ & $\mathbf{4 5 . 1}$ & $\mathbf{7 6 . 1}$ \\
Peninsula & & & & & & & & & & & \\
Magreb and & 54.5 & 59.9 & 64.0 & 79.6 & 69.1 & 74.9 & 42.5 & 39.2 & 32.9 & 30.7 & 52.5 \\
Marrakesh & & & & & & & & & & & \\
Black Africa & 52.1 & 46.8 & 65.2 & 72.0 & 78.2 & 75.4 & 40.0 & 37.8 & 26.7 & 23.8 & 54.7 \\
Ex Communist & 55.4 & 60.1 & 78.2 & 89.1 & 79.3 & 68.5 & 36.7 & 38.3 & 23.3 & 21.5 & 59.6 \\
Asia & 55.6 & 63.2 & 65.1 & 78.4 & 88.6 & 72.8 & 32.5 & 35.0 & 33.8 & 29.5 & 57.3 \\
Iran & 44.6 & 60.6 & 57.4 & 81.0 & 79.7 & 60.1 & 10 & 10 & 10 & 25 & 52.4 \\
Turkey & 61.6 & 69.9 & 86.6 & 73.2 & 83.4 & 71.1 & 50 & 50 & 50 & 41 & 40.3
\end{tabular}

Sources: www.heritage.org, author's calculation of averages: 1 Business Freedom; 2 Trade Freedom; 3 Fiscal Freedom; 4 Government Freedom (size of government); 5 Monetary Freedom; 6 Investment Freedom; 7 Financial Freedom; 8 Property Freedom; 9 Freedom from corruption; and 10 Labour Freedom.

\subsection{Colonial Heritage and Institutional Design}

The past concerns not only Islamic law and a rent-seeking model, but also European colonisation. Like most countries, Muslim countries received their basic legal structures involuntarily through conquest and European colonisation. Just as Arab conquests transplanted the pre-Islamic law culture into non-Arab countries (Senegal, Indonesia, Turkey), European conquests imported European legal traditions such as common law and civil law. In addition to common law and French civil law, three legal traditions play some role in parts of the world: German code, socialist law, and indigenous Nordic or Scandinavian legal traditions (La Porta, Lopez-de-Silanes, Shleifer and Vishny, 1998, Botero et al. 2004, p. 1345). According to Mulligan and Shleifer (2005), Muslim countries inherited their broad legal traditions from their colonisers. They accepted path dependency, because it was an efficient adaptation. Path dependency is a means to minimising the cost of the enforcement of laws in order to protect the value of human capital and coordinate with the old coloniser. The evolution of institutions in the Muslim world began with the decline of the Turkish Empire and colonisation mainly by the French and British. This shows both the importance of institutional competition in institutional design and the role of colonisation (violence).

\subsubsection{Decline of the Turkish Empire}

In the nineteenth and twentieth centuries, the Ottoman authorities and the colonising Europeans conceived Islam to be an obstacle to economic development and the adoption of capitalism. For this reason, they tried to modernise Muslim law and practices. For Khadduri (1946), the Turkish defeat by the Russians in 1774 was at the origin of plans to introduce Western concepts into these institutions. This would later (1839-1856, Tanzimat) lead onto the Sultan instituting the equality of rights for Muslims and Christians and the creation of civil courts. These measures were, however, never supported by religious authorities. They announced liberal reforms in 1909-1918 and later, through the actions of Mustafa Kemal 
Atatürk, went as far as to impose Western-style suits for men (law of 1925) (Kuran, 1997b, p. 315 ) and to adopt the civil code. The Turks during this period tried to modernise law and morality in their country. We can suppose then that the Turkish presence was rather favourable towards liberalisation.

Iran chose the same strategy of modernisation from 1906 to 1979. In 1935, it banned the veil for women and forced men to wear Western clothes. This choice was, nevertheless, constrained by the coloniser. This is a good example of foreign-introduced exogenous institutions (Boettke, Coyne and Leeson, 2008, p. 342), when "the distance between the process of institutional design and the location of hoped institutional "take-hold" is considerable". This explains the failure of these reforms in Iran. On the contrary, Turkey is an example of indigenously introduced endogenous institutions (Boettke, Coyne and Leeson, 2008, p. 337), which has been more successful.

\subsubsection{British and French colonisation}

The judicial traditions of the colonists also play a role. For instance, La Porta, Lopez-deSilanes, Shleifer, and Vishny (1998) considered the Islamic past less important than was the influence of Western colonialism. They place legal system into four Western-centric families: English common law or the French, German, or Scandinavian commercial codes. In their sample, the legal origin of Malaysia, Nigeria, and Pakistan is English common law. The legal origin of Egypt, Indonesia, Jordan, and Turkey is the French commercial code. The history of the economic models of Muslim countries is, under these conditions, a story of restricted institutional choices. Furthermore, the Russians invented a new economic model and introduced Soviet law in 1917. Behind these five traditions, five economic models formed, namely Anglo-Saxon, French, German, and Scandinavian capitalism and the Soviet model. The ideal of a Westernised Muslim city in a liberalist or socialist sense can then only inflect the relationship that could exist between Muslim law, based on the interpretation of the sacred texts, and today's law. This inflexion, imposed or chosen, explains, in the framework of the institutional dependence path theory, why some countries are more liberal than others are. Globally it is accepted that British colonisation bequeathed a more liberal judicial tradition than the French, Spanish, and Russian (Soviet) continental traditions (Scully, 1987, La Porta, Lopez-de-Silanes, Shleifer and Vishny, 1998, North, 1990, Shirley, 2004, pp. 617-618). Spain transplanted its centralised government and hegemonic property rights developed by the nobility to its colonies in Latin America. England brought its decentralised, limited government to its colonies. As a result, the United States and Canada were better positioned to create good institutions for development than were Latin American countries (Shirley, 2004, p. 617).

For Muslim countries, British colonisation explains the high economic freedom in the Persian Gulf, namely in Bahrain, Oman, Qatar, Kuwait, UAE, Malaysia, and Saudi Arabia (Table 4). Jordan is no exception. Countries occupied by France are generally classed among the countries that are less free (Guinea, Senegal, Mali, Algeria, Djibouti, Mauritania, Niger, Syria, Chad, Lebanon, Tunisia, and Morocco). Nevertheless, countries colonised by the British are not always carriers of high economic freedom (see Pakistan, Sierra Leone, Bangladesh, and Nigeria). Therefore, other factors exist to explain the institutional design. The choice of political elite at the time of independence can also explain these differences. The choice of institutions - during a time of independence as determined by the Cold War and the opposition between two models -was between capitalism and Soviet socialism. In this period, the ideals of the Islamic city were compared with foreign models. It should be said 
that Islam was compatible with liberal capitalism or socialism. The issue is the doctrinal translation of institution competition between capitalism and socialism.

Table 4

Economic Freedom 2009, Western Empires and Muslim Countries

\begin{tabular}{|c|c|c|c|c|c|c|c|c|}
\hline \multicolumn{3}{|c|}{ British Empire $^{7}$} & \multicolumn{3}{c|}{ French Empire $^{8}$} & \multicolumn{3}{c|}{ Soviet Empire $^{9}$} \\
\hline $\begin{array}{c}\text { Average } \\
\text { (total) }\end{array}$ & $\begin{array}{c}\text { Average } \\
\text { Muslim } \\
\text { Countries }\end{array}$ & $\begin{array}{c}\text { Average } \\
\text { Non- } \\
\text { Muslim } \\
\text { Countries }\end{array}$ & $\begin{array}{c}\text { Average } \\
\text { (total) }\end{array}$ & $\begin{array}{c}\text { Average } \\
\text { Muslim } \\
\text { Countries }\end{array}$ & $\begin{array}{c}\text { Average } \\
\text { Non- } \\
\text { Muslim } \\
\text { Countries }\end{array}$ & $\begin{array}{c}\text { Average } \\
\text { (total) }\end{array}$ & $\begin{array}{c}\text { Average } \\
\text { Muslim } \\
\text { Countries }\end{array}$ & $\begin{array}{c}\text { Average } \\
\text { Non- } \\
\text { Muslim } \\
\text { Countries }\end{array}$ \\
\hline $\mathbf{6 0 . 5 7}$ & 60.75 & 60.59 & $\mathbf{5 3 . 6 8}$ & 53.85 & 53.73 & $\mathbf{5 8 . 7 6}$ & 54.86 & 61.35 \\
\hline
\end{tabular}

Source: Economic Freedom index, www.heritage.org report 2009

Thus, three major events explain the link between Muslim countries and liberal capitalism in the nineteenth and twentieth centuries: the institution competition between the Ottoman Empire and Europe, colonisation, and the choice of economic model after independence. These choices explain the various levels of economic liberalism among Muslim countries as well as the existence of different institutional trajectories and the singularity of each country (Table 5).

\subsection{The fall of the Berlin Wall}

After the Second World War, a political leader could choose socialism. With the fall of the Berlin Wall and the collapse of the Soviet model, this choice created prohibitive justification costs for the political elite. The collapse of the Soviet model changed the ideological context and this explains why people and political entrepreneurs could no longer believe in real socialism. No alternative existed. Choosing the status quo in these circumstances was a decision contrary to the sense of history and expectations of people. The market transition was almost obvious. Rich countries provided financial assistance to countries formally under Soviet influence.

Therefore, the political image in 1991 was different from that prevailing in 1950 when many countries gained independence. In this context, we must explain the score of economic freedom in Albania, Kyrgyz Republic, and Kazakhstan (moderately free, Table 5) and in Uzbekistan, Azerbaijan, Tajikistan, and Turkmenistan (not very free or not free). At this step of reasoning, Islamic law (legal theory, beliefs, and norms) is just one factor among others to explain their scores for economic freedom. The colonisation heritage, political choices after the Second World War, and the fall of the Berlin Wall dominated religious factors to explain economic freedom in the past century. These evolutions explain why Islamic principles are not consistently applied in contemporary Islamic societies (Hillman, 2007, 270) ${ }^{10}$.

\footnotetext{
${ }^{7}$ Botswana, South Africa, Uganda, Namibia, Swaziland, Kenya, Tanzania, Ghana, Zambia, Gambia, Nigeria, Malawi, Lesotho, Sierra Leone, Hong Kong, Australia, New Zealand, Malaysia, Fiji, Samoa, Pakistan, Sri Lanka, India, Tonga, Micronesia, Maldives, Bangladesh, Solomon Islands, Kiribati, Burma, Bahrain, Oman, Qatar, Kuwait, Jordan, UAE, Yemen, Guyana, Belize, Barbados, Bahamas, Saint Lucia, Trinidad and Tobago, Saint Vincent and the Grenadines (46 countries).

${ }^{8}$ Egypt, Senegal, Mali, Mauritania, Niger, Djibouti, Chad, Comoros, Tunisia, Morocco, Algeria, Syria, Guinea, Lebanon, Madagascar, Benin, Gabon, Ivory Coast, Cameroon, Togo, Central African Republic, Rep of Congo, Vanuatu, Cambodia, Vietnam, Laos (25 countries).

${ }^{9}$ Kyrgyz Republic, Kazakhstan, Azerbaijan, Tajikistan, Uzbekistan, Turkmenistan, Armenia, Belarus, Estonia, Georgia, Latvia, Lithuania, Moldavia, Russia, Ukraine (15 countries).

${ }^{10}$ This fact is also noted by Bin (2008, p. 15) regarding tax policy in Algeria. He cites note 26 of the thesis of Bouderbala, M.A. (2000), La réforme fiscale en Algérie, Thèse Paris 1, 2000, \$ 3 et 4, pp. 8-11.
} 
Table 5

Path Dependency

\begin{tabular}{|c|c|c|c|c|c|}
\hline Countries & Pre-Islamic & $\overline{\text { Islam }}$ & Ottoman & Colonisation & Independence \\
\hline 1 Bahrain 74.8* & Sassanid-Iranian & Empire Arab- $7^{\text {th }}$ c. & yes & British & 1971 \\
\hline 2 Oman 67.0 & Sassanid-Iranian & Empire Arab- $7^{\text {th }} c$. & 1507 Portugal & British & 1980 \\
\hline 3 Qatar 65.8 & Sassanid-Iranian & Empire Arab- $7^{\text {th }} \mathrm{c}$. & yes (1872) & British & 1971 \\
\hline 4 Kuwait 65.6 & Sassanid-Iranian & Empire Arab- $7^{\text {th }} \mathrm{c}$. & yes & British & 1961 \\
\hline 5 UAE 64.7 & Sassanid-Iranian & Empire Arab- $7^{\text {th }} \mathrm{c}$. & yes & British & 1971 \\
\hline 6 Saudi Arabia 64.3 & Sassanid-Iranian & Empire Arab- $7^{\text {th }} \mathrm{c}$. & yes & British & 1932 \\
\hline 7 Jordan 65.4 & $\begin{array}{l}\text { Sassanid- } \\
\text { Byzantium }\end{array}$ & Empire Arab- $7^{\text {th }} c$. & $\begin{array}{c}\text { yes } \\
\left(16 \mathrm{th}-19^{\text {th }} \mathrm{c} .\right)\end{array}$ & British & 1946 \\
\hline 8 Turkey $\mathbf{6 1 . 6}$ & $\begin{array}{l}\text { Sassanid-- } \\
\text { Byzantium }\end{array}$ & $\begin{array}{l}\text { Mercenaries of } \\
\text { Abassid Caliphs }\end{array}$ & yes $X^{\circ}-1912$ & No & 1992 \\
\hline 9 Malaysia 64.6 & Malacca Buddhist & 1414 via China & no & The Netherlands/RU & 1957 \\
\hline 10 Albania 63.7 & $\begin{array}{c}\text { Byzantium- } \\
\text { Christian }\end{array}$ & Ottoman- $15^{\text {th }} \mathrm{c}$. & yes & No & 1991 \\
\hline $\begin{array}{l}10 \text { Kyrgyz Repub. } \\
\text { 61.8 }\end{array}$ & Mongol & Mongol-13 ${ }^{\text {th }} \mathrm{c}$. & no & Russia 1876-Soviet & 1991 \\
\hline 11 Kazakhstan 60.1 & Mongol & Mongol-13 ${ }^{\text {th }} \mathrm{c}$. & no & Russia-Soviet & 1991 \\
\hline 12 Burkina Faso $\mathbf{5 9 . 5}$ & Ghana Empire & via Mali Empire & no & French & 1958 \\
\hline 13 Egypt $\mathbf{5 8 . 0}$ & $\begin{array}{l}\text { Byzantium- } \\
\text { Christian }\end{array}$ & Empire Arab-639 & yes & British-French & 1922 \\
\hline 14 Lebanon 58.1 & $\begin{array}{l}\text { Byzantium- } \\
\text { Christian }\end{array}$ & Empire Arab-637 & yes & French & 1946 \\
\hline 15 Tunisia $\mathbf{5 8 . 0}$ & $\begin{array}{c}\text { Byzantium- } \\
\text { Christian }\end{array}$ & Empire Arab- $8^{\text {th }}$ c. & yes & French & 1956 \\
\hline 16 Azerbaijan $\mathbf{5 8 . 0}$ & $\begin{array}{l}\text { Byzantium- } \\
\text { Christian }\end{array}$ & 667 & yes & Soviet & 1991 \\
\hline 17 Morocco 57.7 & $\begin{array}{c}\text { Byzantium- } \\
\text { Christian }\end{array}$ & Empire Arab- $7^{\text {th }} c$. & no & French & 1956 \\
\hline 18 Pakistan 57.0 & Sassanid-Iranian & $10^{\text {th }} \mathrm{c}$. & no & British & 1947 \\
\hline 19 Yemen $\mathbf{5 6 . 9}$ & Sassanid-Iranian & Empire Arab- $7^{\text {th }}$ c. & yes & Soviet-British & 1969 \\
\hline 20 Algeria 56.6 & $\begin{array}{l}\text { Byzantium- } \\
\text { Christian }\end{array}$ & Empire Arab- $8^{\text {th }} \mathrm{c}$ & yes & French (1830) & 1962 \\
\hline 21 Senegal $\mathbf{5 6 . 3}$ & Songhai Empire & 1050 Mali Empire & no & French & 1960 \\
\hline 22 Gambia $\mathbf{5 5 . 8}$ & Songhai Empire & 1050 Mali Empire & no & British & 1960 \\
\hline 23 Mali 55.6 & $\begin{array}{c}\text { Ghana Empire } \\
(750-1240)\end{array}$ & 1050 Mali Empire & no & French & 1960 \\
\hline 24 Nigeria $\mathbf{5 5 . 1}$ & Songhai Empire & $\begin{array}{c}10^{\text {th }} \text { c. (Arab } \\
\text { Merchant) }\end{array}$ & no & British & 1954 \\
\hline 25 Tajikistan $\mathbf{5 4 . 6}$ & Kouchan Empire & $8^{\text {th }} \mathrm{c}$. & no, Russia & Soviet & 1991 \\
\hline 26 Mauritania 53.9 & $\begin{array}{l}\text { Ghana Empire } \\
(750-1240)\end{array}$ & $7^{\text {th }} \mathrm{c}$. & no & French & 1960 \\
\hline 27 Niger $\mathbf{5 3 . 8}$ & Songhai Empire & 1010 Mali Empire & no & French & 1958 \\
\hline 28 Indonesia 53.4 & Hindus-Buddhist & $15^{\text {th- }} 16^{\text {th }} \mathrm{c}$. & no & Netherlands/Japan & 1945 \\
\hline 29 Djibouti $\mathbf{5 3 . 1}$ & & & & French & 1977 \\
\hline 30 Guinea & $\begin{array}{c}\text { Ghana Empire } \\
(750-1240)\end{array}$ & $10^{\text {th }} \mathrm{c}$. & no & French & 1958 \\
\hline 31 Syria $\mathbf{5 1 . 3}$ & $\begin{array}{c}\text { Byzantium- } \\
\text { Christian }\end{array}$ & 636 & yes (1516) & French & 1946 \\
\hline 32 Maldives $\mathbf{5 1 . 3}$ & & 1153 Sultana & no & British & 1965 \\
\hline 33 Uzbekistan $\mathbf{5 0 . 5}$ & Sassanid-Iranian & 712 & no, Mongol & Soviet & 1991 \\
\hline 34 Sierra Leone $\mathbf{4 7 . 8}$ & & $10^{\text {th }} \mathrm{c}$. & no & British & 1961 \\
\hline 35 Bangladesh $\mathbf{4 7 . 5}$ & Dynasty Buddhist & $12^{\text {th }}$ c. (soufi) & no & India-British & 1971 \\
\hline 36 Chad $\mathbf{4 7 . 5}$ & $\begin{array}{c}\text { Kingdom of } \\
\text { Kanem }\end{array}$ & 1085 & no & French & 1958 \\
\hline $\begin{array}{ll}37 & \text { Guinea-Bissau } \\
\mathbf{4 5 . 4} & \end{array}$ & Ghana Empire & 1050 Mali Empire & no & Portugal & 1974 \\
\hline 38 Iran 44.6 & Sassanids & $7^{\text {th }}$ c. $(637)$ & yes & British-USA & \\
\hline 39 Libya $\mathbf{4 3 . 5}$ & $\begin{array}{c}\text { Byzantium- } \\
\text { Christian } \\
\end{array}$ & $\begin{array}{c}\text { Empire Arab - 632- } \\
661 \\
\end{array}$ & yes & Italy & 1951 \\
\hline 40 Comoros $\mathbf{4 3 . 3}$ & Asian-African & 1676 Sultana & no & French & 1974 \\
\hline $41 \mathrm{Iraq}$ n/a & $\begin{array}{l}\text { Byzantium- } \\
\text { Christian }\end{array}$ & Empire Arab- $7^{\text {th }} \mathrm{c}$. & 1534 & British & 1932 \\
\hline 42 Sudan $n / a$ & Christian $\left(\mathrm{I}^{\circ}\right)$ & 640 & no & British & 1956 \\
\hline 43 Afghanistan n/a & Sassanid-Iranian & $8^{\text {th }} \mathrm{c}$ & no & Soviet & 1992-1996 \\
\hline 44 Somalia n/a & Ethiopian Empire & $13^{\text {th }}$ c. Sultana & no & Italy & 1941 \\
\hline
\end{tabular}

Sources: World Christian Encyclopedia, Economic Freedom index, www.heritage.org report 2009. 
In these conditions, the institutional path dependency of Muslim countries is modified by colonisation, the choices of independence in the context of the Cold War, and the fall of the Berlin Wall, i.e., the failure of the Soviet economic model. It is, in this context, that we must understand the movement of liberalisation initiated in the 1990s under the influence of the International Monetary Fund. The contemporary evolutions show, nevertheless, that liberalisation is instable. There is a revival of Islam, a movement towards socialisation in the most liberal countries in the Muslim world, the development of Islamic finance, and the hostility of Muslim people in general at free market institutions. The instability of liberalisation is the topic of the last section.

\section{The Revival of Islam and Institutional Choices in Muslim Countries}

Liberalisation or socialisation is an institutional change. Institutional change is a political process of mobilising campaigns to legitimate an institutional innovation. The legitimacy refers "to the voluntary acceptance of political authority on the part those who are ruled" (Gallarotti, 1989, note 10). It is a "generalized perception or assumption that the actions of an entity are desirable, proper or appropriate within some socially constructed system of norms, values, beliefs, and definitions" (Schumann, 1995, p. 574). Institutional change is generated by a situation where an agent's beliefs on the ways a game is played are altered critically (Aoki, 2001, p. 231). The generative mechanism of this change is a problem, namely either inefficiency or injustice. North (1981) proposes that the choice of institutions is dictated by efficiency considerations. Efficiency considerations, nevertheless, are institutionally embedded. Efficiency is the norm. It is a social construction. It is legitimate or not. Islam in Muslim countries is the dominant organised belief structure. Islam specifies norms of legitimacy and the learning process by which such a belief structure evolves. Islam is the main ideology in the Muslim world. Ideology provides integrated explanations of the past and present. It is coloured by normative views of how the world should be organised (North, 1990, note 23). Ideological entrepreneurs, in this context, mobilise these cultural and linguistic materials to theorise change and invent the institutional future.

The problems in the Muslim world are numerous: poverty, low education, unemployment, inequality, lack of health policy, low purchasing power, and so on. Muslim countries constitute a sizeable number of underdeveloped countries. Given these social and economic difficulties, people draw on their imaginations to look into the future. The ideological entrepreneur generates a process of the institutionalisation of new ideas. This incarnates change. It justifies the change and legitimates it in an institutionally embedded framework, i.e. Islam. In this context, the legitimacy of reforms is based on religious grounds. The revival of Islam translates into both innovation and intense intellectual debate. The institutional change must be legitimate, and to have this quality ideological entrepreneurs change the common interpretations of the sacred texts and words of God. Institutional change is associated with hermeneutic innovations that prepare the institutionalisation of new ideas and the deinstitutionalisation of old ideas. An institution is, for this reason, the result of a process of the institutionalisation of an idea. An institutional system translates an ideological consistency. The future institution in the Muslim world will be, from this perspective, the result of the process that assumes collective action, diffusion, and enforcement. The ideal of a free market is not shared by many Europeans. It is also opposed by many Muslims who try to resolve inconsistencies and cognitive dissonance from colonisation through the formation of a development model that is not secular but Islamic. This model will be more in agreement with the 'natural' institutional path dependency of the Muslim world, i.e., its embedded framework. For these reasons, it is vital to understand and expect the institutional future of the Muslim 
world to describe its institutional world possibilities and the trends of socialisation, Islamic finance, and hostility at free market institutions.

\subsection{The Revival of Islam and Definition of Institutional World Possibilities}

The question of the institutional adaptation of Muslim countries to European modernity is not new. It gave birth to the forced secularisation policies of Reza Shah in Iran and Atatürk in Turkey, to the Islam political party in India (Jama'ati Islam) (Kuran, 1997b, p. 304), and to Westernisation without renouncement of Islam in Pakistan. It is today the origin of multiple economic doctrines that rival each other in directing future reforms. Modern Islam is the offer of ideology produced by ideological entrepreneurs for political entrepreneurs.

As stated in the introduction, dependence on the past does not only affect the cost of institutional change; it also has an effect on the imagination, the definition of a world of institutional possibilities. All the ideals in Muslim countries are inspired by Shari'a, by an idealised past, a story that becomes utopia. Most debates within Muslim countries refer to what is said by or supposed to be said by Islam on market, democracy, or European modernity.

Without surveying all viewpoints, we can nevertheless see that the political and intellectual elite of Muslim countries propose different diagnoses but all are focused around the religious question. We can cite the Islamic libertarianism of the Minaret of Freedom Institute ${ }^{11}$, moderate Islam, modern radical Islam of Muslim Brothers, Saudi wahhabites, or the Iranian revolution.

Libertarian Islamics uphold that the Koran is profoundly liberal. Several Sura and verses are mobilised to show this. The Koran forbids any forced imposition of Islam (Sura 2, v. 256) ${ }^{12}$, condemns all religious intolerance (Sura 10, v. 108), blesses private property (Sura 2, v. 188) ${ }^{13}$, insists upon the respect of commitments (Sura 2, v. 177 and Sura 5, v. 1), and proposes a number of rules of commercial law (Sura 2, v. 282-283). The decline of the Muslim area is explained by state control, which was devoted to the model of the government of the first Caliphate. In fact, it could have been the European countries that inherited Muslim liberalism via the theologians of the school of Salamanque in Spain in the sixteenth century. There would not, in this sense, be the Muslim world and the West; rather, the two worlds would be one, sharing the same liberal ideals.

Moderate Islam considers that the work of interpreting the sacred texts should be reopened in order to not enclose Islam in laws that are not adapted to the modernity of Muslim countries today. This means adapting Islam to the West's financial practices.

Modern radical Islam proposes, on the contrary, adapting the West's financial practices to Islam. This originates from the creation of the group of Egyptian Muslim brothers created in 1928 by Hasan al Banna (Carré, 1983), in the wahhabism proselytes of Saudi Arabia, and in the reflections that led to the Iranian revolution of 1979. It was prepared by intellectual and political groups in countries such as Iran, Morocco, Libya, Egypt, and Saudi Arabia, who created references common to the Muslim elite who had initially ignored the message of radical modern Islam (Bouba Nouhou, 2005, p. 151). The starting point is that the decline of the Muslim world is explained by Muslims' bad observance of the Koranic

\footnotetext{
${ }^{11}$ The President of Minaret of Freedom Institute is an American, Dean Ahmad. He tries through this organisation to diffuse liberal ideas in the Muslim world.

${ }^{12}$ Le Coran, Les éditions du Jaguar, p. 53.

13 "Do not rob each other unjustly of your goods, using them then to corrupt judges and seizing cynically a good part of others' goods by this infamous method" (Le Coran, édition du Jaguar, p. 37, translation by the author).
} 
precepts. The error of the independent elite is to have sought in the West economic and political solutions to the problems of Muslim countries. All these groups preach a return to Shari'a for this reason, the ideal of the Muslim city. They divide after that on what means should be used to attain this objective. Conservative Islam rejects the West and wishes to defend the patriarchal model of traditional Islam based on community values, authority, and stability. Reformist Islam wishes, rather, to reaffirm the modernisation of faith together with Westernism. This final point is at the origin of the development of an Islamic economic theory and is capable of inspiring an alternative development model (Kuran, 1997b, p. 315). "A complementary objective of Islamic fundamentalism has been to weaken the prevailing commercial and industrial ties between the Muslim world and the West, in order to protect Muslims from un-Islamic influences" (Kuran, 1996, p. 439, Hillman, 2007, p. 274).

Whatever the vision of the ideal Muslim city, the intellectual Muslim proposes legitimate ideological innovation because this is in agreement with the Prophet's word. These innovations use the imaginary perfect Muslim city to convince that they are well founded. The reforms are brought about by ideological entrepreneurs, who perceive personal gain (notoriety, reputation) in the diffusion of the idea and the means of being in agreement with their concept of good (axiological rationality). Their ideas - once taken up by a political leader and/or the people - are at the origin of institutional change. The idea is the seed of change. It is embodied in men, choices, and institutions. The dependence path does not produce only the status quo. It also brings to light human dependence on the world of possibilities. The invention of a new Muslim city built upon the idealisation of the past brings this theory out perfectly. The most influential model is that of fundamentalist or reformist Islam. Their innovations modified profoundly the world of institutional possibilities of most countries in the Muslim world. They make fiction (ideal Muslim city) a reality. They are incarnated in political movements, in people, and in political leaders. They spread and progress in the minds of the political elite, the people, and the judges.

\subsection{Institutional Future in Muslim Countries and Possible Institutional World}

This predominance in the institutional imagination of the ideal of the Muslim city explains the instability of economic liberalism in the Muslim world. It is not because the Gulf countries are freer today than they will be tomorrow. Several facts sustain the thesis of the unsustainability of economic liberalism in the Muslim world: the movement towards socialisation in the most liberal countries (4.2.1), the development of Islamic finance (4.2.2), and the hostility of Muslim people towards free market institutions (4.2.3). Table 6 presents the evolution of economic freedom in Muslim countries (1995-2007). It shows that the countries of the ex-Soviet Empire have liberalised the most during the past twelve years. Table 6 also gives the results of Pitlik (2008, p. 274) and Gwartney, Lawson and Holcombe (1999). There is a dependence effect. The more liberal countries are those that liberalise the

least. We propose two explanations: the cost of liberalisation and the development of Islamic finance.

\subsubsection{The cost of liberalisation}

This effect can be explained by the choices of political entrepreneurs. A state that liberalises loses its power over trade and its capacity to purchase its legitimacy. The opportunity cost of the liberalisation of the economy for the elite in power is weaker in an economy where economic freedom is weaker than it is in a country that has started to make reforms in favour of a free market. Liberalisation in the initial phase cannot touch the interests of the political 
and administrative elite. It is when liberalisation begins to affect more than peripheral public income that it becomes costly for the predator and the reformer (political entrepreneur).

Table 6

Evolution of Economic Freedom in Muslim Countries (1995-2007)

\begin{tabular}{|c|c|c|}
\hline Liberalisation & Status quo & Socialisation \\
\hline Uzbekistan $+65 \%(52.3)$ & Mali 4\% (55.5) & UAE $(-12 \%)(62.8)$ \\
\hline Kazakhstan +42\% (60.5) & Pakistan 2\% & Malaysia (-10\%) (64.5) \\
\hline Tajikistan $+31 \%(54.5)$ & $(56.8)$ & Saudi Arabia (-10\%) (62.8) \\
\hline Albania $+26 \%$ (63.3) & Qatar 1\% (62.2) & Morocco $(-9 \%)(56.4)$ \\
\hline Turkmenistan $+23 \%$ (43.4) & Kuwait 1\% (68.3) & Guinea $(-8 \%)(52.8)$ \\
\hline Kyrgyz Republic $+16 \%$ (61.1) & Jordan 1\% (63) & Bahrain $(-7 \%)(72.2)$ \\
\hline Bangladesh $+24 \%$ (44.9) & Senegal $0 \%$ & Tunisia (-6\%) (59.3) \\
\hline Iran $+22 \%$ (44.0), Egypt $+20 \%$ & $(58.2)$ & Oman $(-6 \%)(67.4)$ \\
\hline$(59.2)$ & Turkey $0 \%$ (59.3) & Sierra Leone $(-6 \%)(48.9)$ \\
\hline $\begin{array}{c}\text { Libya }+17 \%(38.7), \text { Syria }+14 \% \\
(46.6)\end{array}$ & Algeria $(-1 \%)$ & Lebanon $(-3 \%)(60.9)$ \\
\hline & Djibouti $(-2 \%)$ & \\
\hline Nigeria $+18 \%$ (55.5), Mauritania & $(52.3)$ & \\
\hline$+18 \%$ (55.0), Niger $+16 \%(52.7)$ & Indonesia & \\
\hline Chad $+11 \%(47.7)$ & $(-2 \%)(53.9)$ & \\
\hline Burkina Faso $+11 \%(55.6)$ & & \\
\hline Gambia $+8 \%(56.6)$ & & \\
\hline Yemen $7 \%(52.8)$ & & \\
\hline
\end{tabular}

Source: Economic Freedom, www.heritage.org: United Arab Emirates, Malaysia, Saudi Arabia, Morocco, Guinea, Bahrain, Tunisia, Oman, Sierra Leone, Djibouti, Indonesia, Algeria, Turkey, Senegal, Kuwait, Jordan, Qatar, Pakistan, Mali, Yemen, Gambia, Chad, Burkina Faso, Syria, Niger, Kyrgyz Republic, Libya, Mauritania, Nigeria, Egypt, Iran, Turkmenistan, Bangladesh, Albania, Tajikistan, Guinea Bissau, Kazakhstan, Uzbekistan.

Figure 2

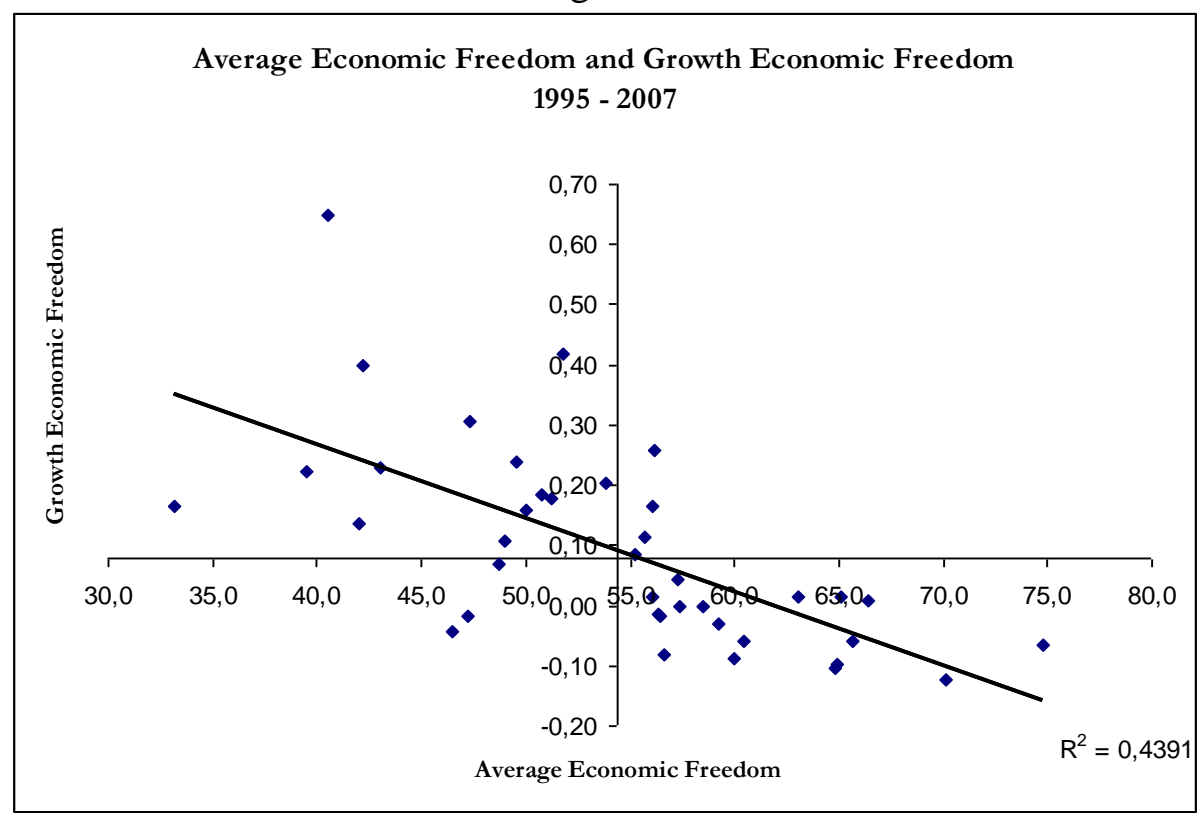

Source: Table 6 


\subsubsection{Development of Islamic finance}

One of the innovations of modern Muslim radicalism is to propose an economic model as an alternative to capitalism (Kuran, 1997b, 2005). The return of Shari'a does not only mean a return to Muslim penal law. It also means the implementation of Islamic finance (Martens, 2001). Islamic finance requires that lenders and borrowers of capital do not define interest (prohibition of usury or riba), share profits and losses, do not speculate (prohibition of incertitude, gharar), rely on real goods or adjacent assets, and do not finance illicit goods such as alcohol, tobacco, gambling, or arms (Martens, 2001, p. 10, Kuran 1997b, 2009, El Qorchi, 2005, p. 47).

Without this being generalised yet, we observe that Islamic financial activity is growing strongly (El Qorchi, 2005, Silva, 2006). Islamic finance is developing at a remarkable pace (El Qorchi, 2005, p. 46), although cross-border data remain scarce. According to The Banker $(05 / 11 / 2007)$, only $42.1 \%$ of banks operating in this market publish data on their Islamic activities. Therefore, the data underestimate the weight of Islamic finance. Estimates of the total size of assets held internationally under Islamic finance vary, ranging upwards from $\$ 800$ billion and with growth rates of $10 \%$ to $15 \%$ annually over the past ten years (Oakley, Bond, O'Murchu and Jones, 2008). Islamic financial institutions developed initially in Malaysia in the 1930s, then in Pakistan in the 1950s and in Egypt in the 1960s (Ariff, 1988). At the beginning of the 1980s, two countries officially introduced a large-scale practice of Islamic finance: Iran and Pakistan (Martens, 2001, p. 2). Nevertheless, Islamic finance is concentrated in the Middle East and Southeast Asia. Saudi Arabia and Malaysia have led to the creation respectively of $25 \%$ and $23 \%$ of Islamic products. If we take just the Islamic obligation (sukuk al ijara ${ }^{14}$ ) their evolution is very quick.

\subsubsection{Hostility of Muslims towards free market institutions}

The progress of radical modern Islam and the millennium practices of classical Muslim law translate concretely into Muslim opinion. Globally, Muslims are hostile to capitalist institutions. Under the hypothesis of the Austrian transition theory, this opposition to the values of freedom threatens the tenability and durability of economic freedom in Muslim countries. It makes the arrival of an Islamic economy credible, an alternative to capitalism inspired by the Koran. Surveys carried out on Muslim beliefs attest to this evolution. They show that Muslims are generally unfavourable to the values of free enterprise economies (Guiso, Sapienza and Zingales 2003, Zingales, 2004, Rajan and Zingales, 2004, Crosette, 2000, Inglehart, 2007). Here, we present only the information that enables us to compare Muslim law with Muslim economic beliefs. We observe that Muslims remain hostile to equality between men and women in the employment market, to competition, and private property. By contrast, they are more favourable to the redistribution of wealth. This corresponds to the ancestral judicial restrictions of Muslim law on private property and individual freedom as described in the first section (Facchini, 2010).

Muslim law does not guarantee strict equality between men and women. It does not give the same rights to men and to women. Surveys show that despite the evolution of law in Muslim countries, mentalities remain attached to these unequal principles. All religions seem rather hostile to women working, but Muslims seem most opposed to this idea (Guiso, Sapienza and Zingales, 2003, p. 228).

\footnotetext{
${ }^{14}$ Sukuk essentially amounts to commercial paper that provides the subscriber with ownership in the underlying asset, namely an asset-backed note.
} 
Inglehart (2007) observed that greater inequality between men and women exists in Islamic societies compared with other societies (especially educational levels) and that this has created a culture of domination, intolerance, and social dependence (Inglehart, 2007, p. 14). Inglehart and Norris (2003) ${ }^{15}$ found that Finland, Sweden, Germany, Canada, and Norway were most favourable to equality between men and women, while Morocco, Egypt, Bangladesh, and Jordan were those countries where inequality was most accepted. For them, religion, and particularly Islam, is the main obstacle to women's emancipation. This result also concurs with the survey of the Pew Research Center for the People and the Press, which showed that in more than half of the Muslim countries surveyed individuals feel that women have no place other than for domestic work( Pew Research Center for the People and the Press, 2003, p. 42). Muslim societies also appear systematically less favourable to women's rights in objective socioeconomic indicators (education, salaries, responsibility, access to contraception, etc.).

Muslims are also hostile to free market institutions, in other words private property, competition, and procedural justice. Private property guarantees free entry or the right to be competitive. It scrupulously respects the principle of procedural justice. To believe that private property is desirable means not fearing competition and not refusing the principles of distributive justice.

Generally, believing in God makes one favourable to a free market. Religions differ, however, in their attitudes to private property (Guiso, Sapienza and Zingales, 2003, Zingales, 2004, p. 59). To the question "In business and industry should private property be favoured?" it is the Buddhists, then the Catholics, Protestants, and Hindus who most often answer "yes". Muslims are least favourable to private property. Muslims are also rather hostile to competition and have a more pronounced taste than do others for redistribution. This is coherent with their hostility to private property and the rent-seeking model. Atheists are most favourable to an equality of revenue. Of religious groups, Muslims and Jews are clearly favourable to an equality of revenue, while Protestants, Hindus, and Buddhists are more favourable to market distribution.

All these facts show that Islam is always present in the institutional imagination of Muslims. It plays a role in the institutional choices of Muslim countries, their business practices, and their ways to justify their decisions. The hostility of opinion towards the free market ethic and the rise of Islamic ethics move Muslim countries away from a free market. Muslims reinforce the idea that religious ideology has an effect on institutional choices in the East. It is not, in this context, obvious that political elites have an incentive to liberalise their economies and protect property rights. The scepticism in the West regarding material progress and economic freedom is not in favour of liberalism in the Muslim world, under the principles of institutional competition.

\section{Conclusion}

This study has enabled us to bring to light the existence of a double institutional dependence path of the Muslim world to Islam. It has shown, firstly, that Muslim countries are generally not free. We explained this situation using the history of the economic models of the Arab and

\footnotetext{
${ }^{15}$ The conferences of Vienna (1993), Cairo (1994), and Beijing (1996) recognised the rights of women and equality of the sexes. This movement is the result of the rising post-materialist values.
} 
Ottoman Empires. This also showed that Muslim countries have been subjected to influences other than Islam. The British influence has been good for economic freedom in the Persian Gulf. By contrast, the French and Soviet influence has been less favourable to economic freedom. These influences explain the Westernisation of the Muslim world.

The effects of Islam have declined in the twentieth century, but the religion's role in the institutional imagination of Muslims has not disappeared. It might even succeed in idealising the past and restoring to Islam its utopian dimension. The twentieth century was the century of Westernisation and, in some countries, of liberalisation. The twenty-first century may welcome the inventing of a different economic model of Western liberal capitalism. We predict that economic freedom in these countries will decline. The history of the twentieth century does not explain the natural trajectory of Muslim countries that are attracted by the ideal of the Muslim city (Shari'a, Islamic finance, etc.). Muslim people do not have as an ideal the free market. The success of modern radical Islam - in the face of alternatives such as a liberal or moderate Islam - weakens the durability and sustainability of liberalisation in this civilisation. Economic liberalism is not the ethical road of the Muslim world. This fact also predicts that liberalisation would not be an economic success. The cultural prerequisites of successful reforms are not met. To succeed, the government should invest in liberal propaganda to explain why liberalism and Islam are reconcilable. Liberalisation is not only hindered by political barriers. It also depends upon the ethical values of the people and political elite. This ethic inspires the world of institutional possibilities and orients their choices. Human action is not only a consequence of the environment because it can make fiction a reality. Therefore, people's institutional imagination is as important as are their experiences.

\section{References}

Aldeeb Abu-Sahlieh, S.A. (2006). Introduction à la société musulmane. Fondements, sources et principes, Eyrolles référence, Paris.

Al Jabri, Mohammed Abed (2007). La raison politique en islam. Hier et aujourd'hui. Editions la découverte, textes à l'appui/ islam et société, Arab translation by Boussif Ouasti, English translation third volume of Naqd al-"aql al-Arabi" entitled Arab-Islamic Philosophy: A Contemporary Critique, trans. Aziz Abbassi, Austin: University of Texas Center for Middle Eastern Studies, 1999.

Aoki, M. (2001). Toward a comparative institutional analysis, Cambridge, Mass: the MIT Press.

Ariff, M. (1988). “Islamic Banking”, Asian Pacific Economic Literature, 2 (2), pp. 46-62.

Asad, M. (1961). The Principles of State and Government in Islam, Berkeley, cited by Scully (1989, p. 600).

Baumol, W. J. (1990). "Entrepreneurship: productive, unproductive, and destructive", Journal of Political Economy, 98, 5 (1), pp. 893-921.

Beach, W.C. and Kane, T. (2008). "Methodology: Measuring the 10 Economic Freedoms", 2008 Index of Economic Freedom, Report 2008, www.heritage.org/index.

Bella, E. (2004). "Fiscal choices and Religion in Ottoman Europe ", Homo oeconomicus, 21 (1), pp. 59-82.

Benabdelali, N. (1999). Le Don et l'anti-économique dans la société arabo-musulmane, EDDIF, Casablanca.

Bin, F. (2008). L'influence de la pensée chrétienne sur les systèmes fiscaux d'Europe Occidentale, L'Harmattan, coll. Finances publiques, Paris. 
Boettke, P., Coyne, C. and Leeson, P.T. (2008). "Institutional Stickiness and the new development economics", American Journal of Economics and Sociology, 67 (2), pp. 331358.

Bouba Nouhou, A. (2005). Islam et politique au Nigeria. Genèse et évolution de la chari'a, Karthala, Paris.

Botero, J.C., Djankov, S., La Porta, R., Lopez-de-Silanes, F. and Shleifer, A. (2004). "The Regulation of Labor ", The Quarterly Journal of Economics, 199 (4), pp. 1339-1382.

Bozarslan, H. (1988). "Réflexions sur l'économie de l'empire ottoman et le passage à la révolution industrielle", Cahiers d'études sur la Méditerranée orientale et le monde turcoiranien, 5, Jan-June.

Brousseau, E. and Glachant, J.M. (2008). "A road map for the guidebook", in Brousseau E. and Glachant J.M. (eds). New Institutional Economics. A Guidebook, Cambridge, Cambridge University Press.

Brown, N.T. '1997). "Sharia and State in the Modern Muslim Middle East", International Journal of Middle East Studies, 29 (3), pp. 359-376.

Brunschvig, R. (1976). " Considérations sociologiques sur le droit musulman ancien ", Etudes d'Islamologie, Maisonneuve Larose, Paris.

Cahen, C. (1961). "Réflexions sur le Waqf ancien", Studia Islamica, 14, pp. 37-56.

Caponera, D.A. (1973). Water Laws in Moslem Countries, FAO Publications 20, 1, FAO, Rome. CAPONERA, D.A. (2003). "La propriété et le transfert de l'eau et des terres dans l'Islam", in FARUQUI N.I., BISWAS, A.K. and BINO, M.J.

Carre, O. (1983). "Le combat pour Dieu et l'Etat islamique chez Sayyid Qotb, l'inspirateur du radicalisme islamique actuel”, Revue Française de science politique, 33 (4), pp. 680-705.

Carre, O. (1986). “A propos de Weber et l'Islam”, Archives de Sciences Soc. des religions, 61 (1), 139-152.

Chapra, U. (2007). "Ibn Khaldun's theory of development: Does it help explain the low performance of the present-day Muslim World?", Journal of Socio-Economics, doi:10.1016/j.socec.2006.12.051.

Chaudhry, K.A. (1994). "Economic Liberalization and the Lineages of the Rentier State", Comparative Politics, 27 (1), pp. 1-25.

Cheddadi, A. (1980). "Le système du pouvoir en Islam d'après Ibn Khaldûn", Annales. Economies, Sociétés, Civilisations, 35 (3), pp. 534-550.

Coulson, N.J. (1995). Histoire du droit islamique, PUF, French translation of A history of Islamic Law, Edinburgh University Press, Edinburgh.

Crosette, B. (2000). "Culture, gender and Human rights", in L.E. Harrison and S.P.

Huntington (ed.) Culture matters: how human values shape economic progress, pp. 178-188, New York Basic.

Denoix, S. (1996). "Introduction: Formes juridiques, enjeux sociaux et stratégies foncières", Revue des mondes musulmans et de la Méditerranée, 79 (1), pp. 9-22.

Diamond, J. (2000, 1997). De l'inégalité parmi les sociétés. Essai sur l'homme et l'environnement dans l'histoire, nrf Gallimard, translated from the English by Pierre Emmanuel Dauzat, Guns, Germs, and Steel. The Fates of Human Societies, W.W. Norton, New York.

El Qorchi, M. (2005). "La finance islamique est en marche", Finances \& Développement, December, pp. 46-49.

European Journal of Political Economy (2003), pp. 395-403, Special Issue "Economic freedom

Facchini, F. (2007). "islam et développement économique ", Sociétal, 57, pp. 79-90. 
Facchini, F. (2010). "Religion, law and development: Islam and Christianity - Why is it in Occident and not in the Orient that man invented the institutions of freedom?", European Journal of Law and Eco., 29, pp. 103-129.

Gallarotti, G.M. (1989). "Legitimacy as a capital asset of the State", Public Choice, 63, pp. 43-61.

Gardet, L. (1930). La Cité Musulmane, Vrin, Paris.

Guiso, L., Sapienza, P. and Zingales, L. (2003). "Does culture affect economic outcomes?", Working Paper NBER, 11999, http://www.nber.org/papers/w1199.

Gwartney, J.D., Lawson, R.A. and Holcombe, R.G. (1999), "Economic Freedom and the Environment for Economic Growth", Journal of Institutional and Theoretical Economics, JITE, 155, pp. 643-663.

Gwartney, J., Lawson, R. and Block, W. (1996). Economic Freedom of the World: 19751995, Vancouver, B.C.: The Fraser Institute.

Habachy, S. (1962). "Property, right, and contract in Muslim Law", Columbia Law Review, 62 (3), pp. 450-473.

Hedlund, S. (2005). Russian Path dependence, London and New York: Routledge.

Hillman, A. and Ursprung, H.W. (2000). "Political culture and economic decline“. European Journal of Political Economy, 16, pp. 189-213.

Hillman, A. (2007). "Economic and security consequences of supreme values", Public Choice, 131, pp. 259-280.

Inglehart, R. (2007). "The Worldviews of Islamic Publics in Global Perspective", in Moaddel M. ed. Values and Perceptions of the Islamic and Middle Eastern Publics, Palgrave Macmillan, USA.

Inglehart, R. and Norris, P. (2003). Rising Tide. Gender Equality and Cultural Change Around the World, Cambridge, Cambridge University Press.

Khadduri, M. (1946). "Human Rights in Islam", Annals of the American Academy of Political and Social Science, 243, pp. 77-81.

Kuran, T. (1995). "Islamic Economics and the Islamic Subeconomy", Journal of Economic Perspective, 9, pp. 155-173 (Chapter 2, Kuran, 2004).

Kuran, T. (1996). " The discontents of Islamic economic morality ", American Economic Review, 86, pp. 438-442.

Kuran, T. (1997a). "Islam and underdevelopment: An old Puzzle Revisited", Journal of Institutional and Theoretical Economics, 153 (1), March and Journal des économistes et des études humaines, 8 (1), March 1998, pp. 27-60, "L'Islam et le sous-développement: un vieux puzzle revisité". (Chapter 6, Kuran, 2004a).

Kuran, T. (1997b). "The genesis of Islamic economics: A chapter in the politics of Muslim society”, Social Research, 64 (2), pp. 301-338 (Chapter 4, Kuran, 2004).

Kuran, T. (2003). "The Islamic commercial crisis: Institutional roots of economic underdevelopment in the Middle East", The Journal of Economic History, 63 (2), pp. 414 446.

Kuran, T. (2004a). Islam and Mammon. The Economic Predicament of Islamism, Princeton University Press.

Kuran, T. (2004b). "Why the Middle East is economically underdeveloped: Historical mechanism of institutional stagnation", Journal of Economic Perspectives, 18 (3), pp. 71-90.

Kuran, T. (2009). "Explaining the economic trajectories of civilization: the systemic approach", Journal of Economic Behavior \& Organization, 71 (3), pp. 593-605.

La Porta, R., Lopez-de-Silanes, F., Shleifer, A. and Vishny, R. (1997). "Legal determinants of external finance", Journal of Finance, 52, pp. 1131-1150.

Lewis, B. (2005). L'Islam, Paris, Gallimard. 
Liebowitz, S.J. and Margolis, S.E. (1995). "Path Dependence, Lock-in, and History", JLEO, 11 (1), pp. 205-226.

Linant de Bellefonds, Y. (1959). "Un problème de sociologie juridique: les terres 'communes', en pays d'Islam", Studia Islamica, 10, pp. 111-136.

Martens, A. (2001). "La Finance islamique: Fondements, Théorie et Réalité", Cahier 202001, Centre de Recherche et de développement en économique, Université de Montréal.

Montgomery Watt, W. (1968), La pensée politique de l'islam, PUF, Paris, French translation of Islamic Political Thought, (1968), Edinburgh University Press, Edinburgh.

Montgomery Watt, W. (1956). Muhammad at Medina, Oxford, University Press.

Mulligan, C. and Shleifer, A. (2005). "The extent of the Market and the Supply of Regulation", Quarterly Journal of Economics, 120, (4), 1445 - 1473.

North, D.C. (1981). Structure and Change in Economic History, W.W. Norton \& Company, New York. London.

North, D.C. (1990). Institutions, Institutional Change and Economic Performance, Political Economy of Institutions and Decisions, Cambridge University Press, Cambridge.

North, D.C. (1997). "The process of Economic Change", The United Nations University, WIDER, Working Papers, No. 128, March.

North, D.C. (2005). Understanding the Process of Economic Change, Princeton, NJ: Princeton University Press.

Oakley, D., Bonds, S., O’Murchu, C., and Jones, C. (2008). "Islamic Finance Explained", Financial Times, May 30.

Pejovich, S. (2008). Law, Informal Rules and Economic Performance. The Case for Common Law. Edward Elgar.

Pierson, P. (2000). "Increasing Returns, Path dependence, and the Study of Politics", The American Political Science Review, 94 (2), pp. 251-267.

Pitlik, H. (2008). "The impact of growth performance and political regime type on economic policy liberalization”, Kyklos, 61 (2), pp. 258-278.

Planhol, de X. (1968). Les fondements géographiques de l'histoire de l'Islam, Flammarion, éditeur, Paris.

Rajan, R.G. and Zingales, L. (2004). Capitalism from the Capitalist, Random House.

Ross R. (2001), «Does Oil Hinder Democracy ? », World Policies, April, pp.325 - 361.

Sait, S. and Lim H. (2006). Land, Law and Islam. Property and Human Rights in the Muslim World, UN-HABITAT, ZED Books.

Schacht, J. (1964). An Introduction of Islamic Law, Oxford, French translation of Introduction au droit musulman, Paris, 1999.

Schumann, M.C. (1995). "Managing Legitimacy: strategic and institutional approaches", The Academic of Management Review, 20 (3), pp. 571-610.

Scully G.W. (1988), "The institutional framework and economic development", Journal of Political Economy, 96 (3), pp. 652-662.

Scully, G.W. (1987). "The choice of law and the extent of liberty", Journal of Institutional and Theoretical Economics (JITE), 143, pp. 595-615.

Sutcliffe, C.R. (1975). "Is Islam an obstacle to development? Ideal patterns of belief versus actual patterns of behaviour", The Journal of Developing Areas, 10, pp. 77-82.

Shatzmiller, M. (2001). "Islamic institutions and property rights: The case of the 'Public Good' Waqf", Journal of the Economic and Social History of the Orient, 44 (1), pp. 44-74.

Shirley, M.M. (2004). "Institutions and Development", in NIE (2004), The Handbook for New Institutional Economics, in Claude Ménard and Mary M. Shirley (eds), Norwell, MA: Kluwer Academic Publishers.

Silva, M. (2006). "Islamic Banking Remarks", Law and Business Review of the Americas, Spring, 12, 2. 
Spindler Z.A. (1991), "Liberty and development: A further empirical perspective", Public Choice, 69, pp. 197-210.

Tocqueville, A. De la Démocratie en Amérique (1840, 1996, p.94), Garnier-Flammarion, Paris.

Turner, B.S. (1974), "Islam, capitalism and the Weber Theses", The British Journal of Sociology, 25 (2), pp. 230-243.

Tyan, E. (1977). "Fatwa", Encyclopédie de l'Islam 2, 886.

De Vanssay X. and Spindler Z.A. (1994), "Freedom and growth: Do constitutions matter?", Public Choice, 78, pp. 359-372.

Voigt, S. (2005). "Islam and the institutions of a Free Society", The Independent Review, X (1), pp. 59-82.

Von Benda-Beckmann, F. (1995). "Anthropological Approaches to Property Law and Economics", European Journal of Law and Economics, 2, pp. 309-336.

Zingales S, L. (2004). "In God we Trust? Comment les attitudes religieuses influencent l'économie", La Recherche, 14, Special Series, Dieu et les sciences, Janvier. Available at the following address.

http://faculty.chicagogsb.edu/luigi.zingales/research/PSpapers/godwetrust.pdf

Zywicki, T. (2000). "Was Hayek right about group selection after all", Review essay of "Unto Others: The Evolution and Psychology of unselfish behaviour", by Elliot Sober and David Sloan Wilson, The Review of Austrian Economics, 13 (1), pp. 81-95. 